\title{
Moral authority and status in International Relations: Good states and the social dimension of status seeking
}

\author{
William C. Wohlforth
}

Daniel Webster Professor, Dartmouth College

Benjamin de Carvalho

Senior Research Fellow, NUPI

Halvard Leira*

Senior Research Fellow, NUPI

Iver B. Neumann

Research Professor, NUPI

\begin{abstract}
We develop scholarship on status in international politics by focusing on the social dimension of small and middle power status politics. This vantage opens a new window on the widely-discussed strategies social actors may use to maintain and enhance their status, showing how social creativity, mobility, and competition can all be system-supporting under some conditions. We extract lessons for other thorny issues in status research, notably questions concerning when, if ever, status is a good in itself; whether it must be a positional good; and how states measure it.
\end{abstract}

\section{Keywords}

Status; Foreign Policy, Small and Middle Powers; Moral Authority; Good States; Norway

\section{Introduction}

'While there is considerable agreement within the political science discipline and foreign policy community that status matters in world affairs', Jonathan Renshon writes, 'the depth of our understanding has lagged far behind our confidence.' ${ }^{1}$ Part of the problem concerns the methodological challenges Renshon has in mind, but part has to do with an unwarranted focus on a restricted research question concerning great powers and war. The consensus that status matters - and that it is especially resistant to social science inquiry - is based almost exclusively on research on great powers. If the general consensus about status seeking is true, however, we would expect status concerns to manifest themselves down the inter-state hierarchy as well.

* Correspondence to: Halvard Leira, Senior Research Fellow, NUPI, PB 8159 Dept, 0033 Oslo, Norway. Author's email: hl@nupi.no

${ }^{1}$ Jonathan Renshon, Fighting for Status (Princeton, NJ: Princeton University Press, 2017), p. 3. 
Building on earlier work, ${ }^{2}$ we extract implications for the social dimensions of the international politics of status by focusing on smaller states. This move allows us to reduce the salience of some confounding issues that plague great power status politics, especially the complex interactions among status, reputation, and security seeking. Our aim is to broaden the field of status research by showcasing the range of policies states - large and small - pursue in order to improve their international standing. We proceed in four sections. First, we unpack the standard claim that status is social, demonstrating that claim's key implications for smaller states. Using this lens, we then reframe standard applications of social identity theory (SIT) concerning status enhancement strategies, emphasising the idea of seeking to maintain a position or climb the global pecking order by being recognised as a 'good' state. This quest for moral authority as a route to status can be reflected in all the ideal type strategies identified in SIT, and all of them can be system-supporting rather than conflictual. With the aim of broadening the research project, the third section examines these arguments in the case of the main actor in our previous research, Norway. Building on this foundation, in the fourth and concluding section we extract other implications for ongoing status research.

\section{Status is social}

Status in international politics is a state's 'standing, or rank, in a status community', ${ }^{3}$ which, in turn, is related to 'collective beliefs about a given state's ranking on valued attributes'. As Renshon emphasises, ${ }^{4}$ these definitions (and others) make clear that status is positional (it assumes meaning to actors in comparison with other relevant actors); it is perceptual (it is what people think of self and others); and it is social (the beliefs in play are collective beliefs about a given actor's standing in relation to others). Each of these qualities is crucial but here we focus on the social dimension as arguably the higher order quality. Status is all about social relations between states. It is not about A's view of B or vice versa. Rather, it is about social facts, that is, widely-held but malleable beliefs in a community. This community may consist of peers or non-peers; in any case, its actors make up what we, following Erik Ringmar, may call a 'circle of recognition' for a specific actor's status claims. ${ }^{5}$ These higher order, collective beliefs determine an actor's status. When a state is dissatisfied with its status, those collective beliefs are the source of the problem. When a state seeks status, those collective beliefs are the object of its efforts.

While the social nature of status politics is widely acknowledged, it is important to stress that social relations are not limited to situations of conflicts and crises. On the contrary, states are not only driven to war by status considerations, but are guided by them in their social dealings with other states in the everyday life of international politics. As we have shown elsewhere, ${ }^{6}$ a major consequence of this is that status concerns are not only the prerogative of the powerful few, but also the torment of small and medium states. This implication stands in direct contrast to the once common assumption that status does not matter for smaller states. ${ }^{7}$

${ }^{2}$ Benjamin de Carvalho and Iver B. Neumann (eds), Small State Status Seeking (Milton Park: Routledge, 2015).

${ }^{3}$ Renshon, Fighting for Status, p. 33.

${ }^{4}$ Ibid., ch. 2.

${ }^{5}$ Erik Ringmar, Identity, Interest and Action: A Cultural Explanation of Sweden's Intervention in the Thirty Years War (Cambridge: Cambridge University Press, 1996). See also Kristin Haugevik, 'Status, small states and significant others: Re-reading Norway's attraction to Britain in the twentieth century', in De Carvalho and Neumann (eds), Small State Status Seeking, pp. 42-55.

${ }^{6}$ De Carvalho and Neumann (eds), Small State Status Seeking.

${ }^{7}$ Michael D. Wallace, 'Power, status, and international war', Journal of Peace Research, 1:1 (1971), pp. 23-35 (p. 24); Ned R. Lebow, Why Nations Fight (Cambridge: Cambridge University Press, 2010), p. 74. 
Indeed, smaller powers suffer from status insecurity to an extent that established great powers do not, which makes the status game even more important to them. The status seeking of small and middle powers, then, must be distinguished from that of greater powers. Smaller states have limited power resources - so, for them, aiming for status may well be the only game in town. ${ }^{8}$ Furthermore, status seeking does not occur in a vacuum. 'Status' means the condition of filling a place in a social hierarchy. Granted that the circle of recognition of status claims to being a great power consists of all states in a given system, all great powers depend on non-great powers to acknowledge their greatness, and so small and middle powers also play a role in constituting great powers.

The concept of status is used to refer to actor identities that emerge out of such processes, as well as to the positioning of actors in hierarchies. Allan Dafoe, Renshon, and Paul Huth see these meanings as distinct, and for analytical purposes, it can make sense to keep them apart. ${ }^{9}$ Socially, however, identities, and most certainly state identities, are hierarchised. Take the identity of a 'small state': it is constituted in relation to great powers, and is therefore intrinsically hierarchical. Status seeking refers to acts undertaken to maintain or better one's placement. As this is something that is done in competition with others, it is by definition a hierarchised activity. Particularly in the case of small states that are heavily integrated in global politics, international status seeking cannot be separated from domestic legitimation games. A state's place in the hierarchy of states is also its place on the map of global politics. It is through their status that states are emplaced and located on the political map of the world. Status seeking is, therefore, a subcategory of state identity politics. It follows that status is intrinsically coupled with the concept of recognition. There will be no status without recognition. While it is common to view recognition, as linked to agency, and status as linked to structure, we reject this static dichotomy. In our perspective, structure is ever emergent, and it is thus continuously constituted and reconstituted through both attempts at gaining status and the giving or withholding of recognition.

Status is thus the result of an intersubjective process and status seeking is a core state activity. Though status has intrinsic rewards, it may also be instrumental, often highly so. States, however, do not seek status from one another in equal measure. States gauge status in relation to relevant comparison groups. The experimental literature converges on a finding that an actor will make comparisons with others that are 'similar but upward' - that is, to others that are similar on key dimensions but have higher status. ${ }^{10}$ Applied to the great power setting, this implies a strictly limited peer group. Given their much greater numbers, small states face a more complex setting for status comparisons. We may distinguish between two types of peer groups for smaller states, functional and ideational. Of the functional peer groups of a state, the most obvious one is that composed of its neighbours. Regional groups are also status groups. ${ }^{11}$ As to more ideational groups, these involve the states that a given state sees as its immediate competitors.

${ }^{8}$ Our claim is not that status concerns are constant - there are, for instance, obvious differences between satisfied states seeking to maintain status and aspiring states seeking to increase status. Thus, while we expect all states to be concerned about status, we see the scope and intensity of this concern as variable.

9 Allan Dafoe, Jonathan Renshon, and Paul Huth, 'Reputation and status as motives for war', Annual Review of Political Science, 17 (2004), pp. 371-93.

${ }^{10}$ Rupert Brow and Gabi Haeger, 'Compared to what? Comparison choice in an inter-nation context', European Journal of Social Psychology, 29 (1999), pp. 31-42.

${ }^{11}$ K. Cline, J. P. Rhamey, A. Henshaw, A. Sedziaka, A. Tandon, and T. J. Volgy, 'Identifying regional powers and their status', in T. J. Volgy, R. Corbetta, K. A. Grant, and R. G. Baird (eds), Major Powers and the Quest for Status in International Politics: Global and Regional Perspectives (New York: Palgrave Macmillan, 2011); T. J. Volgy, P. Bezerra, J. Cramer, J. P. Rhamey Jr, 'The case for comparative regional analysis in international politics', International Studies Review (2017), available at: \{www.https://doi.org/10.1093/isr/vix011\}. 
Among these smaller states, status will tend to have positional quality in that its value will be a function of comparisons with others, not on some absolute or inter-temporal scale.

In the case of Norway, for example, the ideational status group is the so-called 'group of like-minded countries'. These are what Norwegian diplomats might call the 'usual suspects': fairly small, fairly wealthy, democratic, and all eager to spread their moral capital. In empirical terms, the peer group will vary slightly according to the issue-area, but it can be said to consist loosely of what in development circles is known as the Utstein Group (except for the UK and Germany): namely Canada, the Netherlands, Norway, Sweden, Switzerland, and Finland. ${ }^{12}$ If we add Denmark to this list, we have the full peer group. We have here a group of small- and middle-sized states that are both rich and democratic. Norway may compete with Fiji and Nepal over troop contributions to UN peace operations or with Qatar over humanitarian relief, but the competition that matters is with its recognised peers.

The social essence of status means that the relevant peer group can emerge from social intercourse (and a state may seek to 'choose the right pond' in which to excel, in Robert Frank's phrase), but relatively immoveable aspects of the international system do constrain options. ${ }^{13}$ Functional and ideational peer groups may converge. Everything else being equal, we would expect states within the same region to vie more with one another over status than they would with other (non-neighbouring) states.

\section{Status seeking strategies for small and middle powers: Moral authority and status as a 'good power'}

As Thomas J. Volgy and colleagues note, 'there is a paucity of systematic, empirical examination of the correlates of status attribution for states that are not major powers or rising powers'. ${ }^{14}$ The upshot of the discussion so far is that this oversight imposes analytical costs, because the alternative lens can usefully reframe central issues in status research. In general, the social setting of small and middle state status politics enables a different array of status seeking strategies than typically discussed in the great power areas. In particular, strategies of affirming status by being a conspicuously good or moral actors become feasible. In contrast to much of the focus of extant research, the outcome may be system-supporting, stabilising behaviour. ${ }^{15}$

\section{SIT and state strategic choices}

The dominant tendency in the IR literature is to use status motivations to explain socially suboptimal behaviour. Recent major contributions to the status research project fit right in this mold. ${ }^{16}$ Recognising that status is social, these authors nonetheless generally limit international society to

12 The Utstein Group itself was initiated by Norwegian Minister of International Development Hilde Frafjord Johnson in 1998, and can be seen as an attempt to institutionalise Norway's peer group.

${ }^{13}$ Robert H. Frank, Choosing the Right Pond: Human Behavior and the Quest for Status (New York: Oxford University Press, 1985).

${ }^{14}$ Volgy et al. (eds), Major Powers and the Quest for Status in International Politics.

15 Given our argument is that small and middle powers follow distinctly different strategies than great powers, and the fact that the boundary between small and middle is both socially constructed and permeable, we do not distinguish explicitly between small power strategies and middle power strategies here, focusing instead on their commonalites.

${ }^{16}$ See, in particular, Deborah Larson, T. V. Paul, and William Wohlforth (eds), Status and World Order (Cambridge: Cambridge University Press, 2014); Jonathan Renshon, Fighting for Status (Princeton, NJ: 
great powers, and zero in on conspicuous, costly, and often bloody efforts to create a new set of collective beliefs in the relevant peer group concerning status rank. A related line of research uses status competition to explain conspicuous consumption, such as unnecessary and expensive weapons (for example, aircraft carriers), prestige-driven 'big science' projects, superfluous national airlines, and other signature industries, etc. ${ }^{17}$ Again, we see costly, suboptimal behaviour meant to move collective great power beliefs about status.

In seeking to identify the conditions under which status seeking leads to geopolitically competitive behaviour, much of this literature relies on social identity theory (SIT). Following Deborah Larson and Alexei Shevchenko's pioneering work, scholars adapt from the experimental work in social psychology three strategies for improving a state's status: mobility (emulating the values and institutions of referent status superiors); competition (seeking to match or surpass a higher referent state in the very dimensions on which its position is based); and creativity (seeking to change socially approved status-conferring dimensions to those in which the state excels). ${ }^{18}$ Whether status seeking leads to conflict or other suboptimal outcomes depends on strategic choice, with the standard assumption being that mobility and creativity may be conducive to system-supporting and potentially less costly or self-defeating behaviour.

There is considerable debate over how well these strategies translate from the experimental findings in social-psychology to international politics. ${ }^{19}$ For us, however, two points matter most. First, the fundamental question at issue in these studies is whether actors will choose status seeking strategies that lead to geopolitically competitive behaviour. Second, although this literature refers to 'states', the real subject is the highly restricted category of great powers. Left underexplored are the strategies and means that do not relate directly to great power competition. A focus on smaller states provides new insights into how various strategies work. The key is that these powers have something great powers don't: great powers lording it over them who can through word or deed powerfully affect collective beliefs about smaller states' status. This different social context for smaller states, coupled with the difference in resource endowments, creates a different menu of strategies than great powers face.

Smaller states' status-aims are twofold. On the one hand, they seek standing in one or more peer groups of similar states. On the other hand, they might seek recognition by great powers, as useful allies, impartial arbiters, or contributors to systems maintenance. Being (by definition) not great, these states have difficulties in being seen. Great powerhood is about being a state to be reckoned with: smaller powers risk going unnoticed. As such, achieving status just below - not alongside - the great powers is for those states in lower ranks a guarantee of being noticed. And while gaining

Princeton University Press, 2017); Lebow, Why Nations Fight; Steven Ward, Status and the Challenge of Rising Powers (Cambridge: Cambridge University Press, 2017).

${ }^{17}$ Lilach Gilady, 'Conspicuous Waste in International Relations' (unpublished PhD thesis, Yale University, 2006); Xiaoyu Pu and Randall Schweller, 'Status signaling, multiple audiences, and China's blue-water naval ambition', in Larson, Paul, and Wohlforth (eds), Status and World Order, pp. 141-61; and Michelle Murray, The Struggle for Recognition in International Relations (Oxford: Oxford University Press, forthcoming).

${ }^{18}$ Deborah Larson and Alexei Shevchenko, 'Shortcut to greatness: the new thinking and the revolution in Soviet foreign policy’, International Organization, 57:1 (2005), pp. 77-109.

19 See Steven Ward, 'Lost in translation: Social identity theory and the study of status in world politics', International Studies Quarterly (forthcoming); and Jacques E. C. Hymans, 'Applying Social Identity Theory to the Study of International Politics: A Caution and an Agenda', paper originally prepared for presentation at the International Studies Association convention, New Orleans, Louisiana (24-7 March 2002), on p. 6. 
recognition as a state is in many ways the most fundamental and crucial of statuses, it is of little avail if one cannot interact with other states in some specific capacity, as something. An entity needs qualities, and these qualities may give status. It is only through interaction with other states that this status is recognised - and status is central in opening up more arenas where this interaction can unfold in increasingly more important ways.

Just as there are clubs within the club of great powers (for example, superpowers or world powers), there is a shifting array of socially constructed subrankings among smaller powers. A frequently invoked threshold is that between small and middle powers: small powers remain fairly nondescript, whereas middle powers are recognised for one or more specific quality. The Netherlands is a traditional provider of international law, Switzerland specialises in third-party roles, Canada mediates across the Atlantic. Norway, for its part, has long sought to be identified as a do-gooder state. The suggestion that specific qualities characterise middle powers is a specification of extant literature, which defines small and middle powers in terms either of self- and other-ascribed identity, structural position in the system, behaviour, or what kind of impact they have international qprocesses. Andrew F. Cooper, Richard A. Higgott, and Kim Nossal note that behaviour such as seeking compromise and multilateral solutions are typical of middle powers ${ }^{20}$ Eduard Jordaan, who stresses structural position, sees such behaviour as a virtue of necessity, ${ }^{21}$ and Carr highlights how such behaviour must have some kind of impact to sustain middle powerhood. ${ }^{22}$ All this is relevant to our undertaking. Adam Chapnick notes how middle powers are 'status seekers'; we would add the meta-point that the entire literature on middle powers may be seen as part and parcel of that status seeking, since we are talking about knowledge production that explicitly attempts to shore up the status of certain states as having specific qualities that make them more than small states. ${ }^{23}$ The literature on middle powers routinely appropriates Norway as a middle power.

For small states, access to the great power club is not possible, but access to the status of middle power might be attainable, particularly since this is a category with loose membership criteria. In particular, while the status markers of great powerhood have consistently featured material (and especially military) power - which has the overall effect of pushing great power status politics into geopoliticially competitive directions - status markers on the path from small to middle powerhood may be quite different. Under certain conditions a small state may realistically opt for a collective strategy of mobility (as Larson and Shevchenko understand it), into the middle power rank, and this is a distinctly different strategy from the incessant status competition we see among

${ }^{20}$ Andrew F. Cooper, Richard A. Higgott, and Kim Nossal, Relocating Middle Powers: Australia and Canada in a Changing World (Vancouver: University of British Columbia Press, 1993), p. 19. For a critique, see David Black, 'Addressing apartheid: Lessons from Australian, Canadian and Swedish Policies in southern Africa', in Andrew F. Cooper (ed.), Niche Diplomacy: Middle Powers after the Cold War (Houndmills: Macmillan, 1997). See also Allan Patience, 'Imagining middle powers', Australian Journal of International Affairs, 68:2 (2014), pp. 210-24; Niels N. Schia and Ole Jacob Sending, 'Status and sovereign equality: Small states in multilateral settings', in de Carvalho and Neumann (eds), Small State Status Seeking, pp. 73-85.

${ }^{21}$ Eduard Jordaan, 'The concept of a middle power in International Relations: Distinguishing between emerging and traditional middle powers', Politikon: South African Journal of Political Studies, 30:1 (2003), pp. 165-81; also Satoshi Ikeda, 'Zonal structures and the trajectories of Canada, Mexico, Australia and Norway', in Marjorie Griffin Cohen and Stephen Clarkson (eds), Governing Under Stress: Middle Powers and the Challenge of Globalization (London: Zed Books, 2004), pp. 263-390.

${ }^{22}$ Andrew Carr, 'Is Australia a middle power? A systemic impact approach', Australian Journal of International Affairs, 68:1 (2014), pp. 70-84.

23 Adam Chapnick, 'The middle power', Canadian Foreign Policy Journal, 7:2 (1999), pp. 73-82 (p. 76). 
small powers or middle powers themselves. Such status mobility is typically rooted in emulation of acknowledged middle power practices, such as taking on extended responsibilities for preserving international order. Competition, on the other hand, occurs along any number of categories relevant to the peer group, from foreign aid to number of fighter jets, athletic prowess, etc. Creativity in status seeking among small and middle power implies launching some new dimension on which status can be measured, such as foreign aid as percentage of GDP. Pushed to its logical conclusion, such creativity can lead to claims that what really matters in international politics is not might but right, and that certain small or middle powers are 'moral' or 'humanitarian' superpowers.

When the Norwegian Ministry of Foreign Affairs (MFA) in the early 2000s started toying with the idea of cashing in on the status gains more explicitly, one approach was to tout Norway as a 'humanitarian superpower'. This branding met with domestic opposition, and when Jonas Gahr Støre took over as foreign minister in 2005, Norwegian diplomats were reportedly asked to refrain from referring to the 'superpower' image, and to settle instead for the more modest 'humanitarian great power'. ${ }^{24}$ This is indicative of the extent to which status matters for smaller states, and ties in with other concerns. As a case in point, The New York Times in 2014 reported on how Norway had supported US NGOs' work on topics relevant to Norwegian priorities, with a view for these policies to achieve higher visibility in Washington, DC. Furthermore, the Norwegian MFA had shown interest in arranging a meeting with US State Department officials: 'The Norway official wished to discuss his country's role as a "middle power" and vital partner of the United States. ${ }^{25}$

Small states clearly do not seek status from great powers by seeking to match them materially but some degree of emulation can pay off. Indeed, some of the same elements over which small and middle powers compete among themselves, also give status vis-à-vis great powers. Being a major donor to the UN for instance gives competitive status among certain peer groups of small states, but also gives acknowledgement from great powers for system maintenance. A small state may compete for standing vis-à-vis other small states by striving to be seen as complying with great power favoured norms in an especially salient fashion. ${ }^{26}$ Creativity might in this context imply defining new ways in which to be useful for the great powers and systems maintenance, such as when Norway engaged heavily in peace facilitation in the 1990s and 2000s. Hence the behaviour associated with mobility (emulation of norms of the elite group) may reflect a strategy of competition vis-à-vis other lower-status states. Small states might thus join - and bask in the status of - great power-defined and led groups like the 'West' or the 'rules-based liberal order' without ever entertaining the notion of being great powers. When Norway, for instance, plays the dame of useful ally to the US, the diplomats who represent Oslo are in part basking in some of the esteem that accrues to the larger Western identity that the US purports to lead.

\section{Status via moral authority}

Great powers have, by definition, greater access to resources. In the traditional narrative, they have also been seen to corner the market on moral authority. Morality is a question of proper conduct,

${ }^{24}$ See Benjamin de Carvalho and Jon Harald Sande Lie, 'A great power performance: Norway, status and the policy of involvement', in de Carvalho and Neumann (eds), Small State Status Seeking, pp. 56-72.

25 'Foreign powers buy influence at think tanks', The New York Times (6 September 2014), available at: \{https:// www.nytimes.com/2014/09/07/us/politics/foreign-powers-buy-influence-at-think-tanks.html\}.

${ }^{26}$ Jennifer L. Miller, Jacob Cramer, Thomas J. Volgy, Paul Bezerra, Megan Hauser, and Christina Sciabarra, 'Norms, behavioral compliance, and status attribution in international politics', International Interactions, 41:5 (2015), pp. 779-804. 
and proper conduct must be understood in relation to a specific discursive universe. If we leave out the possibility that there exist eternally valid rules of conduct, and think of state morality as a social phenomenon, morality will be proper behaviour as judged within the specific framework laid down historically by the leading powers of the system. Small states, by contrast, have been understood as the opposite of great powers, having fewer resources and less moral authority, left with a policy of reactive pragmatism as their only viable choice. However, as status can depend on at least two variables (in our argument, both power traditionally understood and moral authority), we admit the possibility of status being conferred on both emerging powers (who have more material power, and often little moral authority) as well as on small and middle status quo-oriented states that either develop material niche capabilities or enjoy high moral authority. ${ }^{27}$

The strategy of developing material niche capabilities exemplifies a well-understood logic. It is perhaps best exemplified in the present system by Nepal, whose elite-soldier Gurkha regiment confers on this small state the status of a military power. It is important to note that one set of policies does not preclude the other. Both Denmark and Norway have had great success in offering effective military support alongside the United States in international operations in recent years. ${ }^{28}$

The strategy of exerting moral authority, by contrast, is less well understood. One of the founders of sociology Émile Durkheim stressed:

As long as there are States, so there will be national pride, and nothing can be more warranted.

But societies can have their pride, not in being the greatest or the wealthiest, but in being the most just, the best organized and in possessing the best moral constitution. ${ }^{29}$

Under certain circumstances, then, small and middle powers will seek status along this moral dimension. States may pose as moral in three different ways. They may, first, take their cue from a tradition, that is, an abstract body of maxims. Empirically, European humanism will be such a tradition. In everyday Western speech, it is first and foremost this kind of conduct that is referred to as moral. ${ }^{30}$ To a small state, this form of moral action lends itself to strategies not only of mobility and creativity, but also of competition, within the peer group or even in contrast to great powers. Calling great powers out on their perceived hypocrisy in prioritising power over morality is but one example. Such a strategy of competition might lead to status-gains vis-à-vis a peer group, which are perceived to outweigh status loss with respect to great powers. ${ }^{31}$

Second, states may act morally by sustaining a social order. Support of a given hegemonic order is an example of what might be called 'system maintenance'. Such action is often associated with great

27 See the discussion in Benjamin de Carvalho and Cedric de Coning, Rising Powers and the Future of Peacekeeping and Peacebuilding (Oslo: NOREF, 2013).

${ }^{28}$ Nina Græger, 'From "forces for good" to "forces for status"? Small state military status seeking', in de Carvalho and Neumann (eds), Small State Status Seeking, pp. 86-107.

29 Émile Durkheim, Professional Ethics and Civic Morals (London: Routledge, 1992 [orig. pub. 1913]), p. 75.

30 Since this normative framework is socially and historically constituted, what confers status even in this alleged tradition is also changing. Status research would thud do well to integrate the insights of, for example, Ann Towns, Women and States: Norms and Hierarchies in International Society (Cambridge: Cambridge University Press 2010), Ayse Zarakol, After Defeat: How the East Learned to Live with the West (Cambridge: Cambridge University Press, 2011); Rebecca Adler-Nissen, 'Stigma management in international relations: Transgressive identities, norms, and order in international society', International Organization, 68:1 (2014), pp. 143-76.

31 Sweden's policy of active neutrality during the Cold War might serve as an example of such a strategy of moral competition. 
powers, ${ }^{32}$ but it is an alternative for small and middle powers as well, allowing for all the strategies referred above. ${ }^{33}$ Third, small states may find that they act morally by sustaining the hegemon itself. This approach is usually tied to a strategy of mobility. There are times when these three ways of acting dovetail, as when Norway decided to support the United States in the Korean War (1950s) by sending a field hospital. This was a humanitarian thing to do, it supported American hegemony, and it was seen as useful by the United States. There are also times when they diverge, as when Norway decided to support the military intervention against Gadhafi in Libya by dropping bombs. While running counter to humanitarianism, the rationale of the UN mandate was phrased in humanitarian terms. Norway's active military role arguably supported American hegemony, and was definitely seen as useful by the United States.

Combining the different aspects of morality, we hold that some smaller powers sharing the normative structure of leading great powers of international society, aim for an overarching strategy of being perceived as a good power, by which we mean foregrounding moral conduct. ${ }^{34}$ While small powers, when relating to the great powers, will not challenge them, they will generally aim for a position just below them; alongside - as close as possible - to the hegemon. This quest for status is pursued not through competition or conflict, but by doing what the hegemon may (or may not) deem to be good deeds. The point is that small states hope for some of the great power status to trickle down to them by being the good power alongside the mighty. Vis-à-vis the vast pond of smaller powers, however, creativity may yield major self-esteem payoffs: finding a dimension in which it excels and seeking strategically to attract status to that dimension. And, as mentioned above, within the peer group, strategies of competition, even challenging the great powers, might yield status.

Thus, when small and middle powers engage in status seeking, it is not as a way to compete for great power status. Rather, what some of these states are competing for is the status as a good power. The essence of being good in the sense of engaging in systems maintenance, was neatly captured by former UN Secretary-General Kofi Annan:

It is easy for small nations to feel daunted by the global forces at work ... Large countries with enormous labour forces, abundant natural resources, arsenals of high-tech weaponry and fleets of expert technicians and negotiators may seem to have all the advantages. ... I would like to sound the strongest possible note to the contrary. My long experience at the United Nations has shown me that the small States of the world ... are more than capable of holding their own. I would even go so far as to say that their contributions are the very glue of progressive international cooperation for the common good. ${ }^{35}$

What is there to gain from such involvement? The status of a good power - not to say that of the best of the good powers - allows some states in the small-state myriad to be seen. It allows them to share the limelight with the great powers, and can call forth great power behaviour and speech that can

32 Cf. Hedley Bull, The Anarchical Society: A Study of Order in World Politics (London: Macmillan, 1977).

33 There is a fundamental difference between these actions and great power systems maintenance, not least that whereas a lapse in the latter might lead to systemic upheaval, a lapse in the former will most likely just increase transaction costs.

${ }^{34}$ Our take on good powers is relatively close to Lawler's, with the caveat that in our perspective, 'goodness' is defined by context; Peter Lawler, 'The good state: In praise of “classical” internationalism', Review of International Studies, 31:3 (2005), pp. 427-49.

35 SG/SM/6639, Kofi Annan, 'Secretary-General Lauds Role of Small Countries in Work of United Nations, Noting Crucial Contributions, Press Release' (1998), available at: \{http://www.un.org/News/Press/docs/ 1998/19980715.sgsm6639.html\}. 
move collective beliefs about standing. As Renshon and others argue, it is not easy to alter collective beliefs - conspicuous, salient action is often needed. For smaller powers, great powers can help in this regard, and the trick is to get their attention and induce from them the desired action. A clear example here is when Norway, at the conclusion of the Oslo Process was allowed, at the White House, to perform the role of peacemaker of the Middle East conflict, the 'mother of all conflicts'. Once the role played by a small state has been spotted by a great power, that contribution must be publicly recognised. This recognition typically takes the form of an acknowledgment of the state's contribution in spite of its size. It is thus tempting to venture that it is once small and middle powers stake a claim to being good powers, that their status of primus inter pares can become acknowledged and recognised. As a case in point, note that the wording of choice of President Obama, in recognising the role played a good small ally, is that they 'punch above their weight'. Denmark, Norway, the Netherlands, Ireland, and the Philippines are all countries that were thus recognised by Obama. ${ }^{36}$

As this example demonstrates, however, being a 'good' power does not necessarily mean opting out of the high politics of war and peace. Assuming moral responsibility for orderly maintenance of the international system, especially in matters of international peace and security, has always been one of the hallmarks of high international status and great powerhood - and to a large extent of middle powerhood too. International security affairs remain a great power preoccupation and thus a high-stakes status arena where honour and reputation are in play. Honour and reputation do figure centrally as drivers of foreign policy for small and middle powers. ${ }^{37}$ To take a historical example, when arguing the Norwegian parliament in favour of military aid to Denmark, at the time (1864) under attack from Prussia and Austria, Ole Jacob Broch, declared: 'It is of particular importance for the smaller states, when they see the need to engage in the strife of other states, to do so steadfastly and decisively. For them, honour and prestige are even more important than for the greater powers. ${ }^{38}$ The very fact of Norway's smallness was seen as necessitating a focus on acting in a way that could enhance its status.

Small and middle powers may thus play the status game by involvement in areas that have traditionally been the hallmark of great power status: international peace and security. But, given resource constraints, and when domestic and international norms suggest, they face incentives to attempt to put a 'do good' twist on it. Consider this short statement on Canadian foreign policy after the Second World War:

Participation in international ventures, such as the Korean War, allowed Canada to take an active role in world affairs, but these undertakings did not fully meet the needs of Canadian foreign policy. Canada had not yet found a comfortable role in which to exercise its middle-power status. Neither the functional principle nor the concept of the middle power had been recognized in the United Nations Charter of 1945. ... Ultimately, however, Canada was able to find a niche that was perfectly suited to its national temperament and middle-power status. The role that Canada created for itself was that of mediator and peacemaker. Canada became recognized for its efforts to use quiet diplomacy to resolve international disputes. Even more significantly, these efforts to

${ }^{36}$ See fn. 60. Note how such recognitions confirm often explicitly expressed ambitions and expectations on behalf of middle and aspiring small powers. Beeson's claim is surely generalisable: 'Australian policymakers have always harboured a desire to "punch above their weight”'. Mark Beeson, 'Can Australia save the world? The limits and possibilities of middle power diplomacy', Australian Journal of International Affairs, 65:5 (2011), pp. 563-77 (p. 563).

37 See, for example, Jonathan Mercer, Reputation and International Politics (Ithaca, NY: Cornell University Press, 1996).

${ }^{38}$ St. tid. (1864), p. 21. All translations from Norwegian are by the authors of this article. 'St. tid.' refers to the verbatim records of parliamentary debates. 
broker peace agreements were accompanied by a willingness to participate in UN peacekeeping missions with military force. This peacekeeping role was useful, responsible, and relatively inexpensive. It became a pillar of Canadian foreign policy in the post-war period. ${ }^{39}$

Canada's engagement is indicative of the road taken by many states keen to increase their status without being able to claim that of great power. A small state will see its status rewards exponentially multiplied if it can succeed in fostering international peace and security - that is, in taking on a responsibility that initially rests not upon its shoulders, but on those of the great powers. For small states, taking responsibility for international peace and security beyond what other states could have expected on the basis of size and military resources is one way of gaining recognition as a good power. This status in turn can make it possible for such states to enter arenas from which they would otherwise be excluded. This is why, resourceful small and medium powers, typically Western and prosperous states, spend vast resources on maintaining order in the international system. ${ }^{40}$ But the ability of any smaller state to pursue 'do good' styles of peace and security involvement are partly functions of domestic identity, global norms, and international systemic pressures, as Norway's experience shows.

\section{Norway: Doing good, circumstances permitting}

We have shown that the social nature of status presents small and middle powers with a different menu of options than the usual fare the great power focused literature has highlighted. The strategy of leveraging moral authority and gaining status as a good state is one such option. To optimise impact on the relevant set of collective beliefs, we've suggested that being 'good' in the high politics area of peace and security is attractive. Needless to say, different smaller states in different status communities, with different resource endowments will have different options. There is also the question of path dependency; a small state such as, for example, Montenegro, which has a limited 'do good' track record, will be more constrained in adopting this strategy than will a state that may point to a century-long or more effort of doing so. Here we briefly use the case of one such state, Norway, to begin to establish the possibilities and limits of this approach.

This case study reinforces the extent to which status is social, as well as the limitations of the rewards a state may expect to gain for its status through peace activism. We start by showing how status seeking was central to Norwegian state and nation building even before the country gained independence in 1905, and how size (smallness) became a guarantee of moral authority, allowing Norway to gain access to arenas otherwise reserved for greater powers. Furthermore, we show the continuities of this involvement, as well as its most contemporary manifestations through examining Norway's quest for status through its peace mediation and peacekeeping. Through such policies of becoming involved, Norway seeks status through taking responsibility for international peace and security - an area otherwise a great power domain.

Three circumstantial factors conditioned Norway's longstanding 'good power' strategy: its national identity and domestic political preferences, the changing international setting, which set both possibilities and limits of the strategy, and luck.

${ }^{39}$ This statement is taken from the account of Canadian foreign policy found on the website of the Loyal Edmonton Regiment Museum. It is not an account from an academic treatise but rather an everyday account of Canadian foreign policy. Available at: \{http://www.lermuseum.org/en/canadas-military-history/1945-to-present/peacekeeping/canadas-role/\}.

${ }^{40}$ Iver B. Neumann, 'Institutionalizing peace and reconciliation diplomacy: Third-party reconciliation as systems maintenance', in Ole-Jacob Sending, Vincent Pouliot, and Iver B. Neumann, Diplomacy and the Making of World Politics (Cambridge: Cambridge University Press, 2015), pp. 140-67. 


\section{Identity and domestic politics}

Norway was part of a Copenhagen-led empire from 1380 to 1814, when it entered into a loose union with Sweden. Full independence was achieved in 1905. The first half of the nineteenth century was characterised by a desire to achieve the recognised status of statehood, the second half of the century by efforts to add content to that statehood. ${ }^{41}$ For Norway, liberal conceptions of 'the people' were the key discursive construction in political discourse, ${ }^{42}$ and fit neatly with the international peace discourse of the second half of the nineteenth century, with its emphasis on the peacefulness of the peoples as opposed to the war-proneness of the nobility and kings. And so, when Norwegian liberals began to realise the necessity of conceiving a role for Norway in the wider world, the peace discourse became the starting point for foreign policy discourse. ${ }^{43}$

Discourse among Norwegian intellectuals and policymakers articulated this approach in terms strikingly resonant with the idea of social creativity from social identity theory. The young peace activist, later Norwegian minister of foreign affairs Halvdan Koht, for instance, stressed how being small gave a certain status - a status of not being power seekers, and thus being credible agents of change. ${ }^{44}$ Likewise, whereas it was widely assumed that power gave status, poet and political activist Bjørnstjerne Bjørnson argued that the fact of not having power gave a special status. In a sense this constituted a secular version of the New Testament ideas that the meek shall inherit the earth and that the last shall be first: a moral re-evaluation of interaction among states would make the small states (or indeed the good states) the ones ranked on top. ${ }^{45}$

This was not to be a passive transformation, however, for added to the status of smallness was the status of pursuing peace. While Norwegians wanted to stay out of the game of power politics, they also had a strong desire to change the rules of the game. Actively doing so would give honour, while actual change would lead to a reordering of rank in the system of states and thus greater status for Norway. In the terms suggested here, the strategy was one of creativity, changing the terms of the status-game, and the moral action was related primarily to abstract goodness. Koht and Bjørnson were far from alone in claiming a special place for Norway. In 1896, Dagbladet, the leading liberal newspaper, declared that financial support to the peace movement would be unnecessary, since 'our entire people are natural-born friends of peace'. ${ }^{46}$ The notion that Norway had a self-evident capacity and duty to work for the betterment of the world would prove to be a persistent trait in Norwegian national identity. ${ }^{47}$

\section{International systemic setting}

However, the international setting remained a powerful constraint. Norway was invaded and occupied by Nazi Germany during the Second World War. The war and the ensuing Cold War

${ }^{41}$ Halvard Leira, 'The formative years: Norway as an obsessive status-seeker', in de Carvalho and Neumann (eds), Small State Status Seeking, pp. 22-41.

${ }^{42}$ Iver B. Neumann, 'This little piggy stayed at home: Why Norway is not a member of the EU', in Lene Hansen and Ole Wrver (eds), European Integration and National Identity: The Challenge of the Nordic States (London: Routledge, 2002), pp. 88-129.

${ }^{43}$ Halvard Leira, “"Our entire people are natural born friends of peace": the Norwegian foreign policy of peace', Swiss Political Science Review, 19 (2013), pp. 338-56.

${ }^{44}$ Halvdan Koht, 'Nøitralitetssagen', Dagbladet (6, 7, 8, 11 September 1902).

${ }^{45}$ Bjørnstjerne Bjørnson, Mine brev til Petersburgskija Vjedomosti m.m. (Kristiania: Olaf Norlis forlag, 1898).

${ }^{46}$ [Untitled editorial], Dagbladet (23 April 1896).

${ }^{47}$ Halvard Leira, 'Drømmen om en ny utenrikspolitikk', Nytt Norsk Tidsskrift, $29: 4$ (2012), pp. 383-94. 
brought security issues to the fore as never before in Norway. In unexpected ways, this allowed for new ways of attaining status. In recognition of the war effort of their smaller allies, the allied great powers proposed in 1942 that diplomatic relations between the great and the small within the alliance be upgraded from ministerial to ambassadorial level. Until then, the exchange of ambassadors had primarily been a privilege of the great powers. Norway thus acquired its first ambassador in 1942, before Sweden, which remained neutral throughout the war. ${ }^{48}$ The exclusive linkages between peace and status, already weakened in the years before the war, were further weakened as Norway sought status in a range of different arenas. There was still a broad interest and engagement with peace, and for many, NATO was seen primarily as a peace project, aimed at ensuring security and allowing for constructive peace work in areas where superpower tensions were lower. Following on from its active work in the League of Nations (1919-39), from the very inception of the United Nations, Norway was deeply engaged in its work, and provided troops for UN peacekeeping missions from the late 1940s. Goodness was sought not only on an abstract scale, but also in systems maintenance, following strategies both of mobility and creativity.

Yet although Norway continued its primarily liberal approach to foreign policy, with an emphasis on promoting peace, we should not overestimate the 'peace tradition' or necessarily relate it to status. There was a broad belief in liberal ideas of foreign policy, and a willingness to accept the costs related to standing up for principles, as when Norway protested against NATO membership for Franco's Spain, or against South African apartheid policies. In a status perspective, we could see these policies as elements of a strategy of competition. There was also an element of status seeking related to liberal or solidarity policies more generally, not least in relation to the Third World and development aid. Nevertheless, altruism seems to have been a much more important motivational factor than status in all of these cases, and the Cold War was not an era when peace-related policies were linked explicitly to status.

All this changed after the Cold War, when Norway branded itself as a peace nation once again, with active peace facilitation in several international conflicts. Here we may note that the text laying out the intellectual rationale for humanitarian engagement (human rights rather than peace, but the point proved transferable) relied specifically on the status of smallness. ${ }^{49}$ The 'policy of involvement' as conceptualised by Jan Egeland, ${ }^{50}$ emphasised that small states could play a 'moral' role which greater powers - especially the US - could not, due to the complex web of their global interests. Briefly put: small states had all the tools required to promote the values of a liberal international society; goodness was attained both according to absolute values, and to systems maintenance. That is not to say that Egeland made the case for an altogether altruistic policy. However, the public realisation of the gains in terms of Realpolitik came only later. Being small provided opportunities for making a difference, and smallness could thus serve as a precondition for the acquiring of moral authority. This approach was rooted in a strategy of creativity - changing the scales - but to the extent that the policies were not directly in opposition to US goals, it also contained elements of a strategy of mobility.

Over the past three decades, the policy of involvement has been one of the cornerstones of Norwegian foreign policy. It has also been read into a perceived continuity of policy, going back to the years around 1900 and to the time when human rights were put on the international agenda by the

${ }^{48}$ Iver B. Neumann and Halvard Leira, Aktiv og avventende: Utenrikstjenestens liv 1905-2005 (Oslo: Pax, 2005), pp. 241-2.

${ }^{49}$ Jan Egeland, Impotent Superpower - Potent Small State: Potentials and Limitations of Human Rights Objectives in the Foreign Policies of the United States and Norway (Oslo: Norwegian University Press, 1988).

${ }^{50}$ In Norwegian: engasjementspolitikk, also translated as 'policy of engagement'. 
Jimmy Carter administration. ${ }^{51}$ Between 1978 and 1997, 21,000 Norwegians served in UN peacekeeping forces in Lebanon as part of the United Nations Interim Force in Lebanon (UNIFIL) deployment. This participation paved the way for the major involvements of the 1990s: the peace negotiations in the Middle East - later known as the Oslo Process - and involvement in the Balkans. In terms of status, the Oslo Process was a major Norwegian success, epitomised by former foreign minister Johan Jørgen Holst from 'little Norway' shaking hands with Clinton, Arafat and Rabin on the White House lawn in 1993. This success continued with firm Norwegian involvement in the Balkans, and with former foreign minister Thorvald Stoltenberg at the side of Lord Owen in the Bosnia negotiations. As in the Middle East process, peace negotiations went hand in hand with large amounts of aid. The total Norwegian contribution to the Balkans equalled that of the EU as a whole, and went mainly to Kosovo and Bosnia. ${ }^{52}$ The Norwegian involvement was headed by foreign minister Knut Vollebæk, further strengthened by his role as chairman of the Organization for Security and Co-operation in Europe (OSCE). Norwegian peace mediation has also focused on the Sudans, and Sri Lanka, where Norway served as mediator at the Vatican's initiative. While touted as a success for some time, as with the Oslo Accords, there is wide agreement today that this involvement was less successful. Nevertheless, these processes led the MFA to institutionalise its peace and reconciliation work within a separate unit in $2004 .^{53}$

The similarities with the nineteenth-century Norwegian domestic discourse are striking. And once again - even if this was no longer a particularly important point in a Norway that had become relatively affluent - peace activism proved to give significant status-benefits cheaply. The costs, in time and money, associated with peace engagements were negligible, but recognition of Norway as a peace-oriented state among global policy elites seems to have been both quick and broad. And, as back in the 1890s, domestic resonance was also massive: the idea of being a peace nation struck a deep chord in the Norwegian population. It could well be argued that peace has been even more important for the Norwegian self-image than for the status of Norway abroad. ${ }^{54}$

While the policy of involvement itself may not have been initiated as a way of seeking higher status, its increased intensity towards the end of the Cold War was the result of attempts to stake out a new course for Norwegian foreign policy. Nor did it take long before the political leadership of the MFA came to realise how there was status to gain by being a good power. As stated by one MFA official, 'There is no doubt that the Norwegian involvement in a series of peace processes is what to a large extent gives us access to the tops in the [US] State Department. ${ }^{55}$ As a case in point, then foreign minister Thorbjørn Jagland was the second foreign minister to visit Colin Powell in 2000.

The policy of involvement has increased Norway's status internationally. At least part of the credit for the fact that for many observers Norway managed to attain middle power status in this period is arguably due to this policy. To a large extent, this is due to one specific factor: Norway is perceived as a good power, a

${ }^{51}$ See, for example, Rolf Tamnes, Norsk Utenrikspolitikks Historie, Volume VI: Oljealder 1965-1995 (Oslo: Universitetsforlaget, 1997); Janne Haaland Matlary, Verdidiplomati - Kilde til Makt? En Strategisk Analyse av Norsk Utenrikspolitikk (Oslo: Unipub, 2002).

${ }^{52}$ Matlary, Verdidiplomati, pp. 46-7.

${ }^{53}$ Iver B. Neumann, 'Peace and reconciliation efforts as systems-maintaining diplomacy: the case of Norway', International Journal, 66:3 (2011).

${ }^{54}$ Rolf Tamnes, 'Ettpartistat, småstat og sikkerhetspolitikk', Nytt Norsk Tidsskrift, 3 (1986); Halvard Leira, 2007 (ed.), with Axel Borchgrevink, Nina Græger, Arne Melchior, Eli Stamnes, and Indra Øverland, Norske Selvbilder og Norsk Utenrikspolitikk (Oslo: NUPI, 2007).

${ }^{55}$ Quoted in Matlary, Verdidiplomati, p. 61. 
power perceived not to act solely out of self-interest, but with a view to benefiting international society as a whole; with policies rooted in both abstract goodness and systems maintenance. As a Norwegian diplomat noted, 'I certainly feel that in many contexts I could raise direct bilateral questions because I had raised other issues first [even if] there is a limit to how much attention you can call on as regards Norway's direct interests.' Likewise, former foreign minister Jagland said to his heads of station in 2001:

While we show solidarity and a helping hand to fellow human beings in misery, we become a much more central actor in international politics than what our nature-given preconditions would have made us, something which makes us an experienced contributor and interesting conversation partner, and opens doors which otherwise would have been shut. ${ }^{56}$

And while the policy of involvement has been met with some domestic criticism, this has been spurious and has not altered the general consensus direction of Norway's foreign policy after the Cold War. As a case in point, while Jan Petersen, head of the Conservative Party, who took over as foreign minister in 2001, had been an outspoken critic of the policy of involvement, soon came to realise that the policy of involvement had an effect on Norway's status in the international community that would be unwise not to take advantage of: 'Peace processes make us interesting', he said at a public seminar in 2002, only one year into the job. 'We need a few products like that. ${ }^{57}$ What made Norway interesting and useful to the great powers in the post-Cold War era was its policy of involvement. The importance of the policy of involvement as a key to open otherwise closed doors, especially the doors to Brussels and Washington, seems to have been a key motive for continuing the policy of involvement: ${ }^{58}$

Petersen met his British counterpart Jack Straw. To his [Petersen's] surprise, Straw wanted first to talk about Sri Lanka. The same was the case in the EU. And the US foreign minister Colin Powell asked about Sri Lanka too. Petersen realized that he had diplomatic gold in his hands, and became converted to peace diplomacy. ${ }^{59}$

This awareness of the status dividends of a sizeable international humanitarian involvement has been recognised by most foreign ministers since the end of the Cold War. Knut Vollebæk who sat in the mid-1990s stated that:

I mean ... that our involvement a bit far away not necessarily is an expression of altruism. Even if I mean that it is the expression of a moral attitude and set of values, it is also a matter of Realpolitik. I as foreign minister became for instance interesting in Madeleine Albright's eyes because we were doing things in the Middle East and Africa. And she was the reason why we started our involvement in Haiti ... . It was not because I had such a great desire to involve myself in Haiti, but it was because Madeleine Albright told me: 'We need to work with Haiti, I don't have anyone else. You have done good things in other places, help us'. I think it would have been relatively arrogant and unwise in terms of Realpolitik of me to say no to her. This gave us access also to other fields where I could speak about salmon and other things after a while, and other things after we were done with Haiti. This made us both useful and interesting, and that is an important part of the toolbox [of a foreign minister]. ${ }^{60}$

${ }^{56}$ Quoted in ibid., p. 60.

${ }^{57}$ Quoted in ibid.

${ }^{58}$ Lene Kristoffersen, Interesser i Norsk Engasjementspolitikk (Oslo: IFS, 2009).

${ }^{59}$ Einar Hagvaag, 'I krig for fred', Dagbladet (12 October 2002).

${ }^{60}$ In Sølvi Røen, Jan Risvik, and Benjamin de Carvalho, 'Utenriksministrene Thorvald Stoltenberg, Bjørn Tore Godal, Knut Vollebæk, Thorbjørn Jagland, Jan Petersen og Jonas Gahr Støre i samtale med Jan Egeland', Internasjonal Politikk, 68:1 (2010), p. 102. 
Norway saw returns on its policy of involvement in international peace and security when US President Obama, on the occasion of the visit of Norwegian Prime Minister Jens Stoltenberg to the White House in October 2011, referred to the country as punching above its weight: 'I've said this before but I want to repeat, Norway punches above its weight. ${ }^{61}$ This was as a clear tribute not only to Norway's substantial contributions to the NATO-led bombing of Libya under the auspices of being a humanitarian mission to protect civilians. For as Obama added, 'And their participation in the humanitarian mission [in Libya], protecting civilians, the capacity of Norwegian pilots, their willingness to engage in some very critical missions there, made an enormous difference.' This was a clear indication that Norway is seen as a small state which counts, a middle power, even; the international status of Norway is higher than what one would expect taken into account only the country's size of 5.3 million - that is, smallness. An important factor in Norway's high status is the country's involvement in international peace and security - be it through humanitarian or military means.

\section{Luck and resource endowments}

The best-known example of foreign recognition of Norway's status as a peace nation came when, in 1895, Alfred Nobel of Sweden decided that a committee established by the Norwegian Storting should award a yearly peace prize in his name. That stroke of luck turned into a convenient asset in the 'good state' strategy. While it is not known exactly why Nobel made this decision, it seems logical to surmise that it was related to the peace stance taken by the Storting. Year after year, the Nobel Peace Prize has remained a status marker of peace, internationally and not least within Norway. ${ }^{62}$

Norway first undertook efforts to attain standing as a good state when it was comparatively poor. However, the post-Cold War manifestations of this approach that appear to have been most successful occurred at a time of extreme economic prosperity. Measured against great powers in terms of military power, population, and territory, Norway is undeniably small. But it beats all great powers on some salient metrics such as life expectancy, and dominates most states on most metrics. Norway is the third or fourth richest country in the world, bested only by tiny city-states. Its per capita GDP beats that of the US by 30 per cent and that of Sweden or Denmark by 40 per cent. Though it ranks $115^{\text {th }}$ in population, its astonishing wealth makes its economy the world's $23^{\text {rd }}$ largest. And though it spends only about 1.5 per cent of that economic output on defence, its annual military outlays rank $27^{\text {th }}$ in the world. Its standing on key measures of the quality of life, health, governance, civil, and political rights are generally the envy of most other countries.

Given Norway's outstanding performance on so many levels, it would be surprising if it did not 'punch above its weight' when weight is measured as population or size. So, this comparatively 'nice' experience of status-seeking may be dependent on a very favourable material setting. At least in the modern era, Norway can afford to punch above its weight by 'doing good' expensively.

The UN has been one of the arenas of choice for showcasing Norwegian humanitarian involvement. Norway is a member of the Special Committee on Peacekeeping (C-34), and the annual sessions of

${ }^{61}$ This statement was ambiguous in status terms, as the boxing metaphor was favoured by Obama when describing smaller states. See $\{$ http://projects.washingtonpost.com/obama-speeches/speech/840/\} (25 November 2011), emphasis added.

${ }^{62}$ Ingvild Johnsen, 'Gifts favor the giver: Norway, status and the Nobel Peace Prize', in de Carvalho and Neumann (eds), Small State Status Seeking, pp. 108-25. 
the committee are one of the highlights of Norwegian representation at the UN in New York. However, being a relatively small state with a limited population has not allowed Norway to involve itself in peacekeeping with military contributions at the level of, for example, India or Bangladesh. As a consequence, Norway has sought to be visible through championing causes that mirror its selfidentification as a progressive and peaceful country, so that while neither troop and police contributions nor financial contributions make Norway stand out in terms of peacekeeping, the country is still viewed as one of the strongest proponents of new policies for peacekeeping.

Norway's position is largely the result of the combination of large contributions to smaller but highly visible projects that fall outside of the UN framework. These contributions make it possible for Norway to highlight its own brand of peacekeeping in parallel with UN involvements. UN S/RES/1325 on women and peace adopted by the UN Security Council in 2000 is one such example. Sponsored by Norway, the process leading to the resolution can be traced to Norwegian research institutions, which, in close cooperation with NGOs and the MFA, pushed in a range of arenas for such a resolution.

What has allowed Norway to gain such a position vis-à-vis its peers is less its national wealth in absolute terms. What characterises Norway's policy above all is the willingness to invest in visible international peace projects with guaranteed recognition from the US, combined with a strong willingness to use its disposable income on these projects. This is important when thinking of the potential generalisations or 'lessons learned' of our case. The fact that Norway is a rich country is not what has made these policies possible, as the sums, although important, are not outside the scope of most comparable states. The peace and mediation unit of the MFA, which was institutionalised as a section in 2004, counted only about ten employees with an annual budget of US $\$ 75$ million. $^{63}$

Summing up, this case suggests that for those small states that can do so, taking responsibility for international peace and security beyond what other states could have expected on the basis of size and military resources is one way of gaining recognition as a good power. This status in turn can make it possible for such states to enter arenas from which they are otherwise precluded. To repeat a point, this is why resourceful small and middle powers, typically Western and prosperous states, spend vast resources on maintaining order in the international system.

The result of this competition hinges on recognition from other states, especially great powers. And so, small and middle powers competing for good power status keep close tabs on each other, each one trying to spend more on development and humanitarian aid than the others, and implementing their own 'trademarked' policies or concepts in multilateral settings. When small and middle powers deliberately seek to establish a 'brand name' for themselves in particular ways in relation to other countries - for instance, by having initiated a policy process or focus, a concept or an idea - this, we hypothesise, is done largely in the hopes of being able to reap the rewards of higher status. The aim is not only to be a good power, but the better one.

\section{Conclusion: Broader implications for status in International Relations}

We have shown that the literature on status in International Relations needs to take into account the more quotidian dimension of status seeking, and the fact that status seeking permeates the international system rather than being a 'great power game'. In what follows, we seek to integrate arguments and evidence presented above into more general propositions on status.

${ }^{63}$ Neumann, 'Peace and reconciliation efforts'. 


\section{Do-gooder status seeking}

For certain small and middle powers, conspicuous do-goodism - as opposed to the conspicuous consumption or competition to which great powers are attracted - seems to work in realising the same basic drive for status that the standard model assumes generates competition and war. At least, the examples discussed here (Norway and its peers) suggest this is the case. Indeed, the Norwegian case yields little evidence of much dissatisfaction with the country's standing among either the elites or the voters. And this raises the question of precisely how various kinds of behaviour are linked to the desire for status. The standard model assumes that conflictual behaviour promises that if the actor 'wins' whatever the competitive game may be, this will solve the problem the actor is experiencing with status. If all goes well, the dissatisfied state will win a war, prevail in a crisis, or build a gleaming new fleet of aircraft carriers - and somehow that will bring social responses from key others that are more congenial to the state's self-esteem. In most treatments, this appears to arise from the clear demotion of some other actor - the putative loser of the war or crisis, or the state whose own carrier fleet is somehow devalued. But for Norway, being conspicuously useful or saliently helping to solve problems may well generate a similar result without explicitly defeating or deflating others. And although this almost certainly has the effect of diminishing the social and psychological satisfaction of some competing do-good states (say, Sweden or Denmark) with its own standing, it does not necessarily entail the defeat or demotion of a rival.

This raises the question of how similar the two manifestations of status politics - dangerous or expensive rivalry vs conspicuous do-goodism - really are. Are we really comparing apples to apples? The absence of evidence of deference does give one pause. Small states defer to great powers, seem to win status from some, may indeed attain some standing in their relevant community, but at first glance, do not saliently lord it over other lesser actors. One promising case that needs more work in a status perspective is the one of development aid. It is a standard point in the literature on gift- and aid-giving that, when a gift is not reciprocated, the result may be a fall in status on behalf of the non-giver. ${ }^{64}$ Such a fall in status may induce deference towards the aid-giver. There is a lot of anecdotal evidence that Norway receives this kind of deference in certain contexts, in certain small state receivers of aid. We also note that, Norway's do-good status notwithstanding, both Kenya and Ethiopia have in recent years broken off diplomatic relations with Norway. ${ }^{65}$ This may or may not have happened in the context of status games. We do not know, and these questions await further research. While we wait, given that for some scholars deference is definitive of status, sceptics may wonder how high any small or middle power's standing can be unless more evidence of others' deference is produced.

If we set aside that reservation, the arguments and evidence produced here strongly confirm the claims in the literature that status is social, relational, and positional. States like Norway do not compete with Russia or China for status, but seek instead to distinguish themselves from other smaller states in a setting in which both rival do-gooders and key relevant status-superiors value the cooperative and socially desirable dimensions on which they seek to maintain high standing. For most of recorded history, states or other polities at the top of international systems have valued military prowess and awarded status to victorious competitors. ${ }^{66}$ But if Ned Lebow is right that the

${ }^{64}$ Marcel Mauss, The Gift: Forms and Functions of Exchange in Archaic Societies (London: Cohen \& West; Sahlins: Marshall, 1972); Marcel Mauss, Stone Age Economics (Chicago, IL: Aldine-Atherton, 1970 [orig. pub. 1925]).

65 Axel Borchgrevink, 'Aiding rights? Dilemmas in Norwegian and Swedish development cooperation with Ethiopia', Nordisk tidsskrift for menneskerettigheter, 27:4 (2009), pp. 452-66.

${ }^{66}$ Evan Luard, Types of International Society (New York: Free Press, 1976). 
current international system is on the cusp of a major change in status norms, it is tempting to speculate that, with a different set of status norms, status politics at the great power level could be channeled in a similarly benign direction in a kind of inter-state version of a potlatch society. ${ }^{67}$ Exploring that hypothesis would require careful dyadic studies of rivalry vs cooperation, and conspicuous consumption vs conspicuous do-goodism, as modes of status seeking.

\section{Status as a goal in itself}

Status researchers are divided over whether (or when if ever) status is pursued apart from other more tangible ends. Viewed in light of the postulate that status is social, the debate can seem strangely forced. Examining status politics among smaller states does make it easier (if not easy) to sort out motivations. In Norway's case, even when the country was not only small, but also fairly weak and poor, its elites sought standing; at first the simple categorical recognition as a sovereign state, but later as a distinctive 'peace nation'. Further, the quest to attain, maintain, and advance that distinct status is hard to reduce to the instrumental pursuit of a seat at the table or even the normative conviction in the rightness of the cause. Making a virtue of its small size and exploiting lucky gifts such as the Nobel Peace Prize, Norwegian diplomats have assiduously carved out roles for Norway as facilitator, interlocutor, mediator, and global institution-supporter. Sometimes at significant relative expense, Norway has defended these roles. The result is the strikingly globe-girdling involvement - a seemingly anomalous role for a middle power in the far northwest of Europe.

It is difficult to account for this behaviour without concluding that the quest for status is central to it all. Evidence abounds of costly, time-consuming efforts to enhance position, efforts explained only partly by more instrumental pursuits. What frequently appears to matter is not the intrinsic issue at stake but the impact on the country's standing. The standard explanation for such behaviour is the 'seat at the table' argument. The search for status can yield useful diplomatic influence. Yet when one digs deeper, it is often hard to pin down just what influence Oslo obtained for all its efforts, and in other cases status is sought without even seeking a seat at the table. ${ }^{68}$

\section{Can positionality be avoided?}

Another core proposition in the status literature is that status is a positional good, in that its value depends on social comparison: how much one has in relation to others. High status is in this view inherently scarce, and thus, in comparison with most other valued goods, competitions for status have a greater propensity to become zero-sum. The degree of positionality is a variable, however, and not a constant. It is clearest when status is defined as overall rank and when the issue concerns primacy. It is attenuated to a degree when the status concerns membership in a relatively large group and so begins to resemble a club rather than a positional good. ${ }^{69}$ In addition, some contend, the more social hierarchies there are, the less positional status may be, as actors can seek to be great or outstanding in different areas. Hence, Larson and Shevchenko argue, actors dissatisfied with their rank in a given social hierarchy might seek to excel according to different metrics, or even seek through policies of social creativity to redefine the wellsprings of social status in ways more favourable to those attributes in which they excel.

${ }^{67}$ Lebow, Why Nations Fight; Ned R. Lebow, A Cultural Theory of International Relations (Cambridge: Cambridge University Press, 2008); see also William C. Wohlforth, 'A matter of honor', International Theory, 2/3 (2010), pp. 468-74.

${ }^{68}$ See, for instance, Græger, 'From "forces for good" to "forces for status"?'.

${ }^{69}$ David A. Lake, 'Status, authority and the end of the American century', in Larson, Paul, and Wohlforth (eds), Status and World Order, pp. 246-70. 
Having investigated small and middle state status politics and explored a noteworthy strategy of social creativity - attaining status as a good state - the analysis presented here is probative. The experience of Norway and some of its peers shows that seeking to propel status as something (peace nation, best ally, 'good' state, etc.) allows some small and middle powers to select a hierarchy in which they can do well in the status game by doing good; they can better their position within their peer groups, and even rise from small to middle powers. Still, the evidence suggests that while the positional aspect can be ameliorated, it can never be eliminated. For if there are social and psychological rewards in high standing in some area, others will seek those rewards if they can. If all small and middle powers punch above their weight, none does. And if many punch above their weight, the fact that Norway does as well brings little status. If do-good competitors succeed, if they rise up alongside or ahead of Norway as good state, good ally, or peace state, they diminish the social and psychological utility Norway currently extracts from its status. So competition never goes away entirely. Even when status is defined as membership in a club, when all or most of your peers are also members, membership ceases to imply status.

Thus, states competing for good-power status keep close tabs on each other, each one trying to spend more on development and humanitarian aid than the others, and implementing their own 'trademarked' policies or concepts in multilateral settings. And though this is clearly a 'nice' competition, it is not necessarily an easy one. Norway's material and other assets make it a fearsome competitor in these areas. Its riches allow it to buy expensive weapons, host expensive conferences, support expensive peace and development projects, fund costly peace research institutes, and so on. Its wellordered government and fairly strong elite consensus on its international role lend a strategic purpose and consistency to its efforts. Its formidable portfolio of competitive assets in these areas doubtless deters entry by some would-be rivals.

\section{Measuring status}

One way in which status politics are different for states lower down the hierarchy is the presence of status superiors - far too lofty actually to compete with but nonetheless serving as useful referents. Our case on Norway's experience is rich with evidence of how practitioners actually measure and define status. The processes of definition and measurement are crucial, because in many theories of status politics it is uncertainty about or dissatisfaction with an actor's status that generates conflictual behaviour. Yet the Norwegian experience suggests that small and middle powers get the benefit of being able to look up the inter-state hierarchy for cues as to where they stand with the great powers. The result is to expose a wide array of mechanisms through which actors may reduce uncertainty about their status and a wider array of options for remedying status dissatisfaction. And that, in turn, brings to light new questions about the micro-foundations of the workings of the status motivation in international relations.

\section{Acknowledgements}

A previous version of this article was presented at the $58^{\text {th }}$ Annual Convention of the ISA in Baltimore, 22-5 February 2017. We should like to thank the audience, the three anonymous reviewers of the RIS as well as Kjølv Egeland, Brent Steele, and Paul Beaumont for their comments. Benjamin de Carvalho, Halvard Leira, and Iver B. Neumann acknowledge funding for this article from the Research Council of Norway under the project 'Undermining Hegemony', project no. 240647. 


\section{Biographical information}

William C. Wohlforth is the Daniel Webster Professor in the Department of Government at Dartmouth College, 6108 Silsby Hall, Hanover, NH 03755, United States. He is coeditor, with Alexandra Gheciu, of the Oxford Handbook of International Security, forthcoming in March 2018.

Benjamin de Carvalho is Senior Research Fellow at the Norwegian Institute of International Affairs (NUPI), Pb 8159 Dept, 0033 Oslo, Norway. He is coeditor, with Iver B. Neumann, of Small State Status Seeking (Routledge, 2015).

Halvard Leira is Senior Research Fellow at NUPI, Pb 8159 Dept, 0033 Oslo, Norway. He is coeditor, with Benjamin de Carvalho and Julia Costa Lopez of the Routledge Handbook of Historical International Relations, forthcoming in 2019.

Iver B. Neumann is Research Professor at NUPI, Pb 8159 Dept, 0033 Oslo, Norway. His book with Einar Wigen, The Eurasian Steppe Tradition, 4000 BCE-2018 CE: Russia, Turkey and Eufopean State Building is forthcoming with Cambridge University Press. 